\title{
The Public Relations Acceptance Towards Press Release Application with Artificial Intelligence
}

\author{
Pijar Suciati ${ }^{1}$, Mareta Maulidiyanti ${ }^{2}$, and Ngurah Rangga Wiwesa ${ }^{3}$ \\ 1,2,3 Public Relations Laboratory, Vocational Education Program, Universitas Indonesia, \\ Depok, Indonesia
}

\begin{abstract}
Artificial Intelligence (AI) is gradually changing every industry, including the Public Relations industry (Afzal, 2018). Skills associated with conducting research, creating content, evaluating campaigns, tracking issues and countless work processes are being automated with AI. We believe, although never fully replace public relations professionals but will increasingly assist us and possibly do a better job. We are developing PR Bot, a tool that help PR to create an instant press release using an AI (machine learning). Before we continue building the app, we need to know whether the PR practitioners will accept this technology or not. To find the results we conduct a descriptive research, using interview and polling survey, convenient sampling among the PR professional in Greater Jakarta area. We use Technology Acceptance Model to develop the questionnaire. According to the interview, we found that the knowledge and skill of using new technology of the respondents is very good. The survey shows the acceptance of the perceived ease of use and perceived usefulness of the PR Bot is high. The conclusion, the target market is ready to use the technology, they feel that this tech will help them in daily basis task. Based on this result, we will continue developing and using the insight from the respondents to build the feature of this application.
\end{abstract}

Keywords: Public Relations, Press Release, Artificial intelligence, Machine learning, Automation

KEYWORDS

Public

Relations; Press

Release;

Artificial intelligence;

Machine

\section{INTRODUCTION}

Artificial Intelligence has become the most interesting thing in the world of promotion industry (public relations, marketing, and advertising) today. It is not a robot or machine that governs the world with intelligence that transcends humans; AI is basically the development of programs and computer systems to automate tasks that are the responsibility of individuals. With the availability of an extraordinary amount of data, AI is a power that will help a variety of jobs. AI is gradually changing every industry, including the Public Relations industry (Afzal, 2018). Galloway \& Swiatek (2018) states that the automation of tasks given by AI has many advantages concerning broader technology, economy, and social context that requires more critical attention. With the development of new analytical techniques to help get work done, AI will extend to all 
contexts in Public Relations work. The concern is whether AI will narrow or increase the zone of participation between them and their stakeholders.

Experts and academics recognize that there is great potential in terms of productivity with the presence of AI in the industry. At the same time, AI growth is increasing from individuals and companies. They question the technology that is developing this against their work and approve employment. In the world of Public Relations, there are very few references to the relationship between PR and AI work. As stated by Pavlik (2007) about the discussion of various technologies when dealing with public relations, namely the use of AI in media coverage through systems that use the use of natural language. Other researchers reveal about $\mathrm{AI}$ in discussing the moral compass of public relations, arguing that AI entities and other automata will oppose the public concept of the public (Tilson, 2018) and researchers who see that AI is very strategic as a tool that will help supporters of the works technical and provide flexibility to focus on other activities that are more strategic.

AI has become a term to describe technologies that display human characteristics. In the world of Public Relations there are more and more request of tools with AI. Chartered Institute of Public Relations (CIPR) formed \#AIinPR panel to help understand the impact of technology and specifically artificial intelligence on public relations skills and professions. The CIPR \#AIinPR panel defines AI as a sophisticated application of technology whereby a machine demonstrates human cognitive functions such as learning, analysis and problem solving. Until 2020, \#AIinPR has tagged more than 130 tools. In each case, they have added a description, and labeled each tool based on AI's functionality and sophistication using a five-point scale (Valin, 2018): (1) Simplification - technology that simplifies a public relations process, or provides a tactical service; (2) Listening and monitoring - media and social media listening and monitoring tools; (3) Automation - automation of tactical tasks; (4) AI for structured data - machine intelligence applied to structured data; and (5) AI for unstructured data - machine intelligence applied to unstructured data. The transformation of Public Relations practices in the industry 4.0 is full of technology penetration. The changing of PR activities does not necessarily eliminate the footprint in conventional ways of how PR work (Pambudi et al., 2019).

Many experts agree that AI will help more than hurt white-collar workers by freeing them from more mundane tasks and allowing them to concentrate on innovation and creativity. An Oxford University study called the Future of Jobs by Frey \& Osborne (2013) suggested that millions of workers in the UK are in danger of being replaced by computers and robots. The academic paper looked at 702 of the most common occupations and used a set of algorithms to assign a probability of computerization to occupations, ranking occupations from 0 (no risk of automation) to 1 (very high risk of automation). Public Relations jobs ranked 634 out of 702 jobs (Valin, 2018). 
There are three categories of the Public Relations skill that affected by the AI (Valin, 2018): (1) Skills with zero tech or AI; (2) skills or portions there of that may have a minor contribution from tech or AI tools; and (3) skills where tech or AI is already more prevalent. The AI potential list shows that only a portion of skills $-12 \%$ of total skills (out of 52 skills) are truly using AI ( 4 and 5 on our scale) now with a prediction that this will climb to $38 \%$ within five years. Skills associated with conducting basic research, creating content, evaluating campaigns, tracking issues and countless work processes are being automated or already have some AI. In five years, we see these types of tasks becoming either fully automated or having a high degree of AI applied. The sophistication within these tools will only increase. The extent to which technology or AI will expand will never fully replace public relations professionals but will increasingly assist us and possibly do a better job.

One of content creator skills that a PR should have to support their routine is creating the press release document. Almost every day, PR do this kind of work. This activity has a very close significant achievement with media relations and media monitoring. So, it considered success if the press release can be exposed by as much as mass media (offline/online) and generate a positive tone from the journalist or the editor. Nowadays, people are consuming their news online. Press release is also shifting from the traditional ones published by printed media to digital press release published by online media. According to 2018 research by the Pew Research Center, one in three Americans prefers to read their news online-the second-most-popular medium after television. It's not just consumers who are reading the news online. It's just about everyone. As a matter of fact, press releases are branding and credibility tools, not SEO tools. They are a great way to get the word out about a company, product, or service, and to more effectively brand that company, product, or service.

The content creator process of press release is one of the skills that is predicted will be helped by the automation of AI. The press release writing process is not fully replaced by the AI, but hopefully PR will save a lot of time, if they can be helped by drafting the rough documents. Press release is such a structured written document, which it's statement about a matter of public interest which is given to the press by an organization concerned with the matter.

There are many things that PR should do to prepare the press release, it is a very long process. According to Hannah Williams (2018) the processes in writing press release are: (1) Consider 5W1H; (2) title; (3) introduction sentences; (4) the body; (5) contact details; (6) consider using videos or images; and (7) include links. The key is to make readers lives as easy as possible, include links to any additional information, data, etc. The writing of press release is similar to the journalistic writing, it has to be newsworthy, but in a very compact version. What if, there's a tool that help the PR producing the press release document? How's the acceptance toward this upcoming new Press Release AI tech? We are developing a tool that help PR to create an instant press release using an AI (machine 
learning). Before we continue building the app, we need to know whether the PR practitioners will accept this technology or not. We named the applications, PR Bot.

\section{The Upcoming Press Release Application: PR BOT}

PR Bot is a "Press Release Robot". This application will make it easier to make press releases and distribute them to the press for publication in the mass media. PR Bot can be accessed via website and also via mobile application which can later be downloaded on the Play Store (Android) and Apple Store (iOS). The usage of PR Bot is similar to filling out the form on a questionnaire. The form consists of press release components, such as title, date, $5 \mathrm{~W} 1 \mathrm{H}$, contact person, photo attachments, etc. This application is equipped with a choice of press release types and themes according to the daily needs of a Public Relations practitioners.

\section{Figure 1. PR Bot Logo}

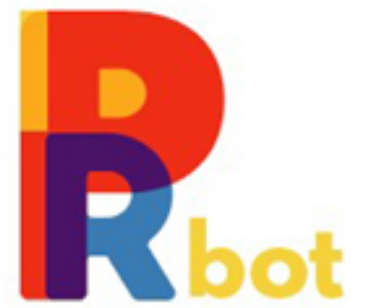

After filling out the form and choosing the theme of the press release, PR can edit and download the press release that has been formed on 1 page. During PR editing, machine learning will learn the grammar, style of language, choice of leads, etc. which are usually done by the PR Bot account owner. Until finally, PR Bot was able to produce a near-perfect press release just by filling in the initial form.

PR Bot also makes it easier for a PR department to process press releases. After the press release is ready, the next step is approval from a higher authority in the PR division. PR Bot has an approval function that can be arranged in advance. The PR Bot account owner can add the head of PR Division account as an approval press release that has been made. New press releases can be distributed to journalists' accounts after obtaining approval from the respective Head of PR Division.

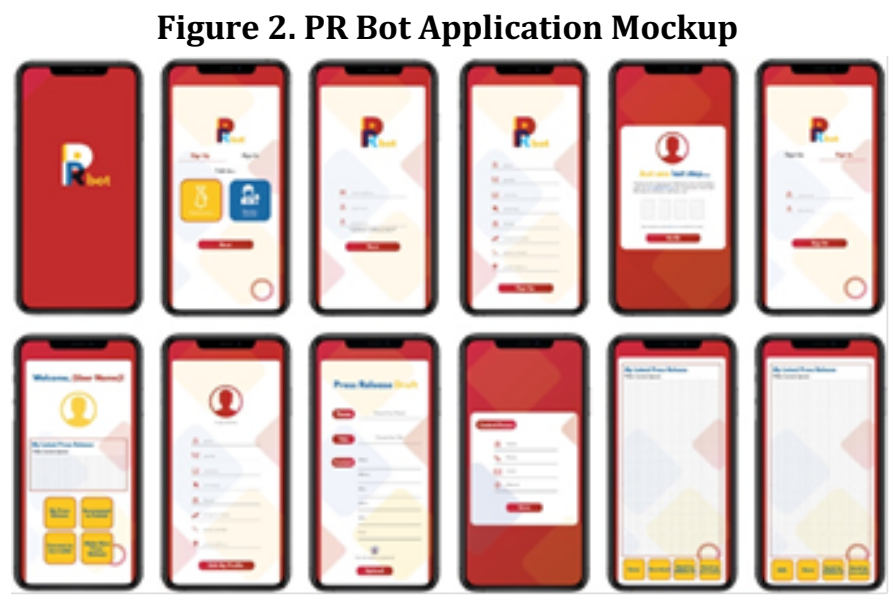


PR Bot can be functioned as a social network between PR practitioners and journalists. In addition to make it easier for PRs to distribute press releases, PR Bot will also make it easier for journalists to get press releases from the fields, types of companies and themes they want to publish in their mass media. Journalists can easily sort through the incoming press releases from PR practitioners they will be connected on PR Bot. So, there are two options when you register a PR Bot, sign up as a PR practitioner or sign up as a journalist. The functions and features of the two types of accounts are different and have been tailored to their respective needs.

\section{Artificial Intelligence in Public Relations}

PR practice has been a change for the past 20 years. The situation and changes in the company also encourage the current role of PR. The industrial revolution also had an impact on the PR profession, so that it could no longer carry out PR activities and programs as usual. In line with the industrial revolution, there has been an evolution in the role, function, and task of PR, as following (Arief \& Saputra, 2019):

First, PR 1.0 is an era where public relations practitioners have to carry out their duties traditionally. This is the era where PR has to do manual monitoring every day. PR practitioners who worked in the 1960-1970's era have experienced this. Print media, such as newspapers, magazines, to television are the main source of information. In addition, PR 1.0 describes a one-way or vertical form of communication from one source of communication to many target audiences, or one to many, so that PR 1.0 describes PR activities as a broadcaster.

Second, PR 2.0 is the era of the birth of online media. PR 2.0 describes horizontal communication, interconnected; communication from many sources to many audiences, or many to many, so that the role of PR is a connector. The characteristic that we remember most about this era is the emergence of various online media, as well as the transformation of print media to switch to digital platforms.

Third, PR 3.0 is an era where social media is the most used, most liked and most trusted media by the public. In this era, activities such as citizen journalism, corporate journalism or employee journalism emerged. A significant change has occurred. In the past, only reporters could make news, now anyone can upload news. Social media Facebook, Twitter, Instagram, YouTube, and blogs have become digital platforms. PR is not only monitoring media - offline and online, but also social media. Good and bad news can come at any time.

And last, PR 4.0 is an era in which artificial intelligence (AI) and big data era are present. The impact of this phenomenon is not felt at this time. However, the fact is that robots are able to write articles in the media and help write, find materials, and other activities. Various tools can be used by PR which serve to simplify the task of PR. Activities such as dissemination of releases to various media, managing company campaigns, tools for 
identifying buzzers, influencers, and manage data of interested parties. In addition, managing platforms for digital content, audio and video as well as managing data analytics can be done using AI technology.

Artificial Intelligence (AI) is predicted to change lives much faster than we imagined. According to Online Publication Quartz (Gershgorn, 2017) AI is software or computer program with a mechanism for learning, then with this knowledge it is used to make decisions in new situations, such as those done by humans. AI is the ability of a machine to use algorithms to learn from data, and use what it has learned to make decisions like humans do. AI is also a system that thinks like humans; Systems that act like humans; Rational thinking systems; and systems that act rationally (Rouhiainen, 2018).

The impact of AI in Public Relations can provide a positive value. For example, in a machine learning algorithm that is equipped with valid data, PR can manage multiple promotions through social media, also allowing engagement between brands and audiences on social media to be increased (Lynch, 2018). AI technology can provide input on sentiment from media coverage, to then send out alerts when negative news arises, so PR professionals can respond more quickly. The research team from the Chartered Institute of Public Relations, Valin (2018) revealed that even though humans have critical thinking skills, some PR activities are threatened and can be replaced by AI. Thus, public relations must strengthen skills such as basic research, content development, program evaluation, issue management, and work processes. Public Relations also requires creativity, the kind of thinking that machines cannot replace, at least to replace the tone of voice or written communication messages or to put creativity into a PR campaign. The ability of public relations equipped with skills in advanced technology such as AI can support the implementation of communication strategies (Dunan \& Mudjiyanto, 2020).

\section{New Application Technology Acceptance}

There are several models that have been used to investigate adoption of technology. To identify intention to use mobile application we can use the Unified Theory of Acceptance and Use of Technology (UTAUT) model. Unified Theory of Acceptance and Use of Technology (UTAUT) is an integrative concept that has been used widely to measure IT adoption (Aufa et al., 2020). Other studies focusing on adoption of mobile services have their roots in Technology Acceptance Model (TAM), originally proposed by Davies in 1986. The purpose of TAM is basically to predict public acceptance of a system and to identify problems that may arise before users actually use the system (Maulidiyanti, 2013). In addition, TAM has also been used to examine what factors influence the intention to use and adopt an information system technology (Venkatesh \& Davis, 2003). TAM measures consumer perceptions of new technology through perceived ease (Perceive Ease of Use) and perceived usefulness (Perceive Usefulness) of a technology. Although TAM was created to predict the level of technology and information system adoption, research in various fields using TAM have emerged (Maulidiyanti, 2013). 
Lederer et al. (2000) examine 15 published studies the existing relations between the perceived ease of use and perceived usefulness in attitudes toward the use of electronic information services over a period of 10 years (from 1989 to 1999). Besides that, King and He (2006) listed 88 studies published on the use of the TAM. The results of this analysis confirmed that the model is predicatively valid, strong, and reliable and can be used in a broad variety of technological contexts, and the impact of its ease of use on the intention of use is mainly based on its perceived usefulness. The study of Lederer, King, and He showed that the TAM is a theoretical model used in various technological contexts that can increase understanding and explain the use of electronic information systems.

There are a number of meta-analyses on the TAM that have demonstrated that it is a valid, robust and powerful model for predicting user acceptance (Bertrand \& Bouchard, 2008). Perceived usefulness and perceived ease of use both have an influence on behavioral intention. Technology users will have an interest in using technology if they find the technology system useful and easy to use. Perceived ease of use also affects perceived usefulness but not vice versa. System users will use the system if the system is useful whether the system is easy to use or difficult to use (Widianto et al., 2020).

\section{METHODOLODY}

The method approach of this research is mixed between qualitative dan quantitative. The nature of this research is exploratory and descriptive. According to Malhotra (2017), exploratory research aims to investigate a problem or situation to gain good knowledge and understanding. Meanwhile, descriptive research aims to describe something. Descriptive research has clear statements about the problems at hand, specific hypotheses, and detailed information required. This study used a single cross-sectional design because data collection from each element of the population was carried out once in a study period. The data used in this study include primary data. Primary data is data obtained directly from interviews and the results of filling out questionnaires by respondents. Apart from interviews, data collection was also carried out using a questionnaire. The questionnaire is a series of formal questionnaires used to obtain information from respondents (Malhotra, 2017).

Population of this research is Public Relations practitioners in Greater Jakarta. Nonprobability sampling is used for the sampling method. Non-probability sampling is a sampling technique based on the personal assessment of the researcher (Malhotra, 2017). Convenience sampling is used because the selected respondents are at the place and time when the research was conducted. Sample selection is done randomly by looking at predetermined criteria, namely Public Relations practitioners who have responsibility for the production of press releases for their companies. his study used a pretest sample of 30 people and also conducted interviews with 30 people at the same 
time. We use the 30 people pretest sample because we want to know the basic understanding of the new technology and the questionnaire for the descriptive data.

This research analyzes the data with descriptive statistics. Descriptive statistics is a statistical data processing method that provides information only about data that is owned and does not intend to test the hypothesis (Hariwijaya \& Budi, 2008). This method aims to make the results of data collection and presentation easier to understand. Descriptive statistics describe the summary of research data such as mean, standard deviation, mode, and variance. In this study, descriptive statistics were used to determine the average respondents' perceptions of the factors in the study.

During the interview, we previously made a treatment in the form of a detailed explanation of the PR Bot application that is being developed. We also showed the respondents a mockup design of this application and detail sequence of how to use it. After we conducted the interviews, we asked them to fill in the poll survey questions that were developed from the Technology Acceptance Model (TAM) and the attitude scale of potential new technology users.

\section{RESULT AND DISCUSSION}

\section{Quantitative Result and Discussion}

From the qualitative side, this research begins by conducting interviews with 30 Public Relations practitioners. Interviews were conducted to obtain data regarding whether these PR practitioners understand well about the development of industry 4.0, especially regarding Artificial Intelligence. From the results of the interviews, we obtained excellent answers to practitioners' knowledge about Industry 4.0. Like a snippet of the following interview answers.

"... Industrial Revolution 4.0 is a phenomenon in human life where the concept of automation is carried out by machines without human intervention in its application ..." (RTS, University PR Staff) ".

"...Industrial Revolution 4.0 is everything in the industry to be dominated by automation, digitization, and the use of cyber..." (NK, Senior PR Consultant).

A good understanding of PRs regarding Industry 4.0 provides the most important foundation for their acceptance and readiness for new technologies that are born in this era. The term industry 4.0 was first coined by the German government in 2011 at the Hannover Fair. They mention this as the beginning of the fourth industrial revolution (Ustundag \& Cevikcan, 2018). Fuchs (2018) defines industry 4.0 as "a concept that deploys a combination of the Internet of Things (IoT), big data, social media, cloud 
computing, sensors, artificial intelligence, robotics and the application of this combination in the production, distribution and use of a product. physical".

At this stage of industry 4.0, the internet does have a big role to play in collaborating with human performance. The device is connected to the machine and everything runs fully automatic, human labor and operational funds can be reduced. However, as a consequence, humans are required to continue to innovate to solve problems. The complexity of the problems in Industry 4.0 is also higher so that traditional solutions are no longer able to overcome them (Mizanie \& Irwansyah, 2019). Everyone from various industrial fields must find new solutions using digital devices that are able to answer existing problems, including people in the Public Relations industry.

Another understanding that is being asked is about Artificial Intelligence which is also one of the supporting parts in industry 4.0. PR practitioners also have a good understanding of AI. PR practitioners consider AI contained in a variety of tools, such as analytic software, design, and writing to be very useful, but among these practitioners there are also those who consider AI as a threat.

"... For me, this AI is like a nightmare. On one hand, it can be good if there is still interaction between PR with one another. This AI reduces the need for interaction with humans in the real world..." (TA, Head of PR Division).

It is undeniable that concerns like this often arise for white collar workers. They are worried that their skills and jobs will be eroded by these robots and their AI. But in fact, the development of good and ethical AI will make it easier for PR in completing routine tasks and have more time to do something that is more strategic, also something that requires creativity. According to Valin \& Gregory (2020) in the book Ethics Guide to Artificial Intelligence in PR, the power of AI makes it interesting or scary depending on your point of view. This technology is growing rapidly in some sectors of the economy, although not as much as in applications for PR, we need to keep an eye on how AI is designed, built, used and asked questions to ensure that AI benefits everyone with clear boundaries to work in the public interest in for everything. All PR practitioners are expected to improve their ability to control AI. Maybe even many PR practitioners who unconsciously use it in their daily work.

The PRs also understand what Machine Learning (ML) is. They can define ML quite well as in the following statement: 
"... Machine Learning is an AI system designed to automatically develop data and behavior of an audience in order to generate insights which are usually good recommendations for brands/consumer ..." (GNS, PR of a Start Up).

“...Machine learning process by analyzing large amounts of data to match algorithms..." (SA, PR Staff one of Indonesian Ministries).

Advance algorithms such as Machine Learning can make a narrative in any style appropriate for a particular audience, appearing as if it was written by a human. Kristian Hammond, one of the founders of Narrative Science, even estimates that by mid-2020, $90 \%$ of news can be generated by an algorithm, mostly without the slightest human intervention (excluding the algorithm design) (Schwab, 2016). A human labor on one side is assisted by the smart devices and machines (human-machine cooperation) and on the other should interact and exchange information with intelligent machines (humanmachine collaboration) (Ansari et al., 2018). When PR has understood what Machine Learning is, they will understand better and will be able to accept, finally use the ML algorithm properly. Public relations practitioners should be aware that much of their work is aided by this technology and must be able to adapt quickly.

This is in line with the results of a research by Arief \& Saputra (2019) New Competencies of Public Relations (PR) in the Era of Artificial Intelligence. It shows that jobs that can be replaced by big data technology and artificial intelligence include news clippings (45\%); analyzing news in the media (45\%); media and stakeholder relations (37\%); social media content management (34\%); release distribution (33\%); photos and videos (24\%). These jobs can be accommodated by a variety of the latest software.

From the interview it can also be concluded that the PR practitioners had very good abilities in using the latest software. They are accustomed to using a variety of computer software and mobile phone applications which will work very similarly to how to use PR Bot. Therefore, it will be very easy for these PR practitioners to use PR Bot in the future.

Another thing that we can summarize from the results of our interviews is related to the difficulties that they face when producing press releases on a regular basis. Here is the summary of their answer:

Table 1. Difficulties Faced by PR Practitioners in Working on a Press Release

\begin{tabular}{cl} 
No & \multicolumn{1}{c}{ Difficulties in Producing Press Release } \\
\hline 1 & Writing technique \\
\hline 2 & Typical technical language of the corporate field \\
\hline 3 & Email technical problem with media (press) \\
\hline 4 & Number of Press Release to be made (quantity) \\
\hline 5 & Obtain material from sources \\
\hline 6 & Determine the key message and writing angle \\
\hline
\end{tabular}




\begin{tabular}{cl}
\hline 7 & Press Release Filing \\
\hline 8 & Obtain research data that supports writing \\
\hline 9 & Slow approval from top management \\
\hline 10 & Number of Press Releases published in the media \\
\hline & Source: Processed Interview Data
\end{tabular}

These 10 points will be the foundation for us in developing the PR Bot features. By accommodating the needs of these PR practitioners, PR Bot will provide the right solution in the process of making Press Release and its distribution.

\section{Quantitative Result and Discussion}

Beside interviews, we also conducted polls with a questionnaire survey. The results of this poll will also help us develop a PR Bot that fits the needs of PR practitioners. This data also illustrates the attitude and acceptance of PR practitioners towards PR Bot as a new technology. The following are general data on technology use behavior from 30 respondents.

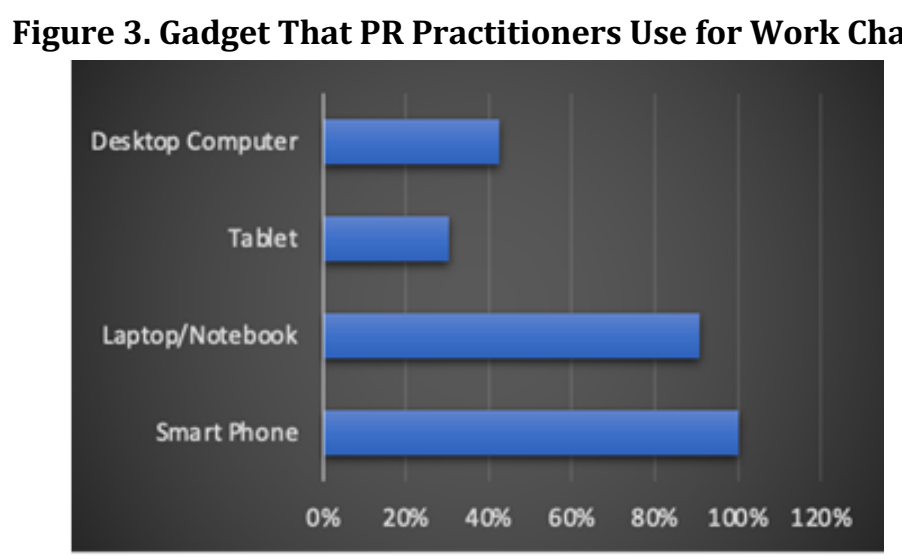

From the data above, it can be interpreted that $100 \%$ of the respondents use smartphones to do their work in the office. The second rank is laptop/notebook, with a rate of $85 \%$. The rest is $40 \%$ using a Desktop Computer and 25\% using a tablet. The analysis of this data is, the respondents maximally use smartphones for work, they are familiar with mobile applications and do not find difficulties to work with smartphone. PR Bot will be available in the form of a mobile application and website, so it can be projected that the target market of this application will have no difficulty in operating it.

Figure 4. Estimated Internet Usage Time Per Day for PR Work

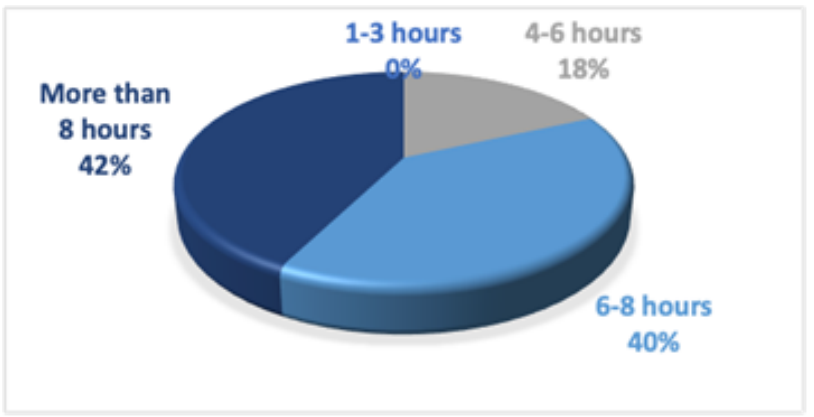


Data from internet usage in a day is also high, namely $42 \%$ of the respondents use the internet for more than 8 hours. The majority of internet usage actually exceeds the set working hours in Indonesia (8 hours). They are also used to working with applications that have to be connected to the internet all the time.

Figure 5. Do you make Press Release every day?

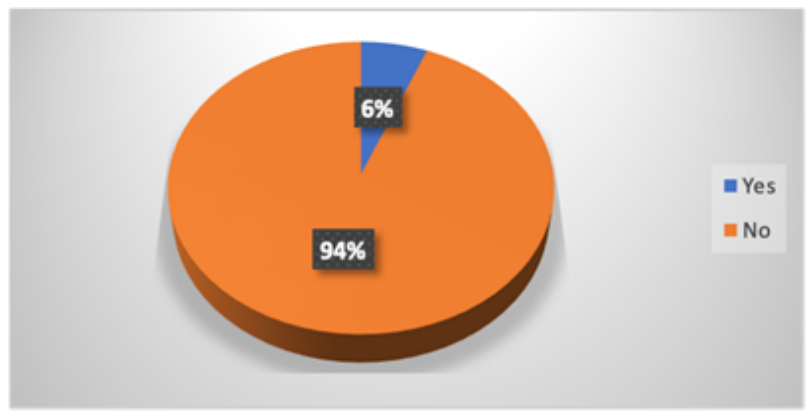

Figure 6. On average, how many press releases do you produce a day?

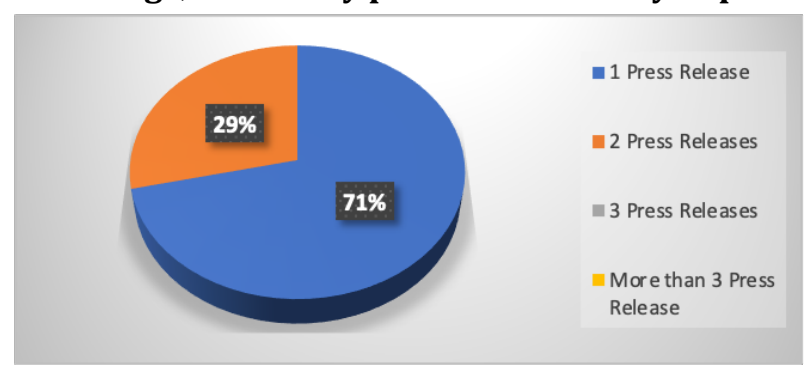

Figure 7. On average, how many times a month do you make a Press Release?

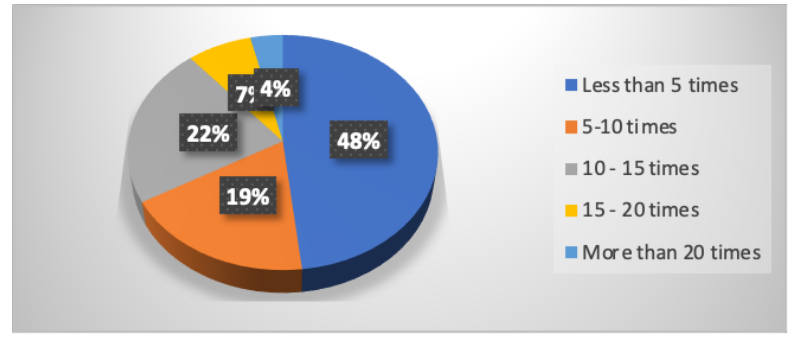

The interpretations of figures 5, 6, 7 are continuous. In Figure 5, only $6 \%$ of all respondents make press releases every day, the remaining 94\% do not make press releases every day. Then in Figure 6, 71\% of the PR who make press releases every day make 1 press release in one day, and the remaining 29\% can make 2 press releases in one day.

Then the next interpretation is about making a press release in one month. In Figure 7, $48 \%$ turn out to make less than 5 press releases within one month. But other interesting data, it turns out that 19\% made 5-10 times, 22\% made 10-15 times. Although the smallest percentage, there were those who made press releases $15-20$ times, then $4 \%$ made more than 20 times per month. This data shows that the Press Release is a routine 
and daily basis work that is patterned and carried out continuously. Press releases can be done in a shorter time and more smoothly in reaching the media when assisted by PR Bot.

Figure 8. Do you use custom templates when creating a Press Release?

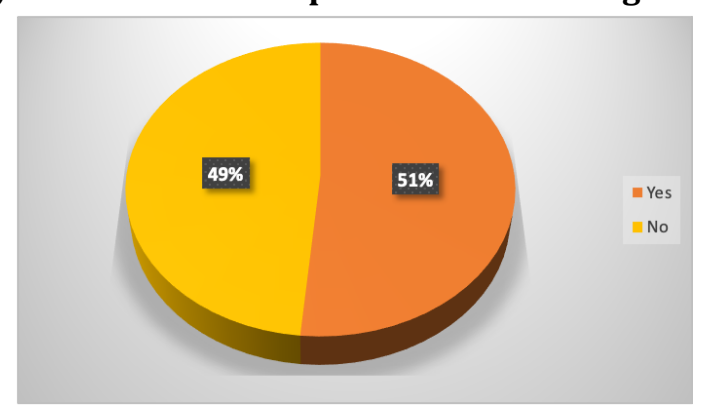

In Figure 8, we can interpret that 51\% respondents answer using a custom template to produce the press releases. From this data, it can be concluded that the making of a press release is something that is very routine, structured, iterative, and can be mapped so that it can be simplified and accelerated with the help of Machine Learning in the PR Bot application.

\section{The Instrument Validity and Reliability Test}

This research is a preliminary study, to do the pretest on 30 respondents. There will be a further research to find causal relationship between these variables. First of all, we tried to find validity and reliability of the research instrument. According to Neuman (2014), the validity test is to examine how well the conceptual and operational definitions are in accordance with one another. The more suitable, the higher the validity. Validity is the degree to which the measurements taken actually measure the concept that was originally to be measured. To test the validity of the instrument, this study uses construct validity which must pay attention to the value of the Keyser Meier Olkin Measure of Sampling Adequacy where the MSA value is declared valid if the KMO value is above 0.5 (KMO> 0.5) (Hair et al., 2014).

Table 2. Validity of Perceived Ease of Use \& Perceived Usefulness Variables

\begin{tabular}{ccc}
\hline Dimension & Number of Indicators & KMO and Bartlett's Test \\
\hline Perceived Ease of Use & 3 & 0,637 \\
Perceived Usefulness & 7 & 0,649 \\
\hline
\end{tabular}

Table 3. Validity of Attitude Variable

\begin{tabular}{ccc}
\hline Dimension & Number of Indicators & KMO and Bartlett's Test \\
\hline Personal Advice & 3 & 0,387 \\
Independent Decision & 3 & 0,481 \\
Making & 3 & \\
Existing Product & 3 & 0,587 \\
Savings & 7 & 0,477 \\
High Tech Product & & 0,667 \\
\hline
\end{tabular}


Instrument reliability is the reliability of an indicator (Neuman, 2014). Research reliability is the degree to which the measurements carried obtain consistent results (over time, among observers, an indicator, etc.). Reliability also refers to the notion that a measuring instrument can be trusted enough to be used as a data collection tool, because the measuring instrument is good. Alpha Cronbach is used to measure reliability in this study because the variables used in the interval scale questionnaire. A measuring instrument is said to be reliable if the Cronbach Alpha Coefficient value is above 0.5.

Table 4. Reliability of Variable Perceived Ease of Use \& Perceived Usefulness

\begin{tabular}{ccc}
\hline Dimension & Number of Indicators & Alpha Cronbach \\
\hline Perceived Ease of Use & 3 & 0,771 \\
Perceived Usefulness & 7 & 0,909 \\
\hline
\end{tabular}

Table 5. Reliability of Variable Attitude

\begin{tabular}{ccc}
\hline Dimension & Number of Indicators & Alpha Cronbach \\
\hline Personal Advice & 3 & 0,263 \\
Independent Decision & 3 & 0,484 \\
Making & 3 & 0.685 \\
Existing Product & 3 & 0,349 \\
Savings & 7 & 0,818 \\
High Tech Product & & \\
\hline
\end{tabular}

Table 6. Reliability of Variable Intention of Use

\begin{tabular}{ccc}
\hline Dimension & Number of Indicators & Alpha Cronbach \\
\hline Intention of Use & 3 & 0,771 \\
\hline
\end{tabular}

According to the results of the validity and reliability test of the TAM dimensions, it was found that several dimensions did not meet the standard values of KMO (Validity) and Alpha Cronbach's (Reliability), they are below 0.5. The dimensions of Perceived Ease of Use, Perceived Usefulness, and Intention of Use can still be used for the next measurement stage. Meanwhile, the dimensions of attitude variable; Personal Advice, Independent Decision Making, and Savings must be removed from this TAM testing instrument.

\section{Descriptive Statistical Analysis}

In the descriptive statistical analysis section, the researcher will describe the results of descriptive statistical processing of the variables studied. This analysis can be continued to the next research for testing the hypothesis of the causal relations between these variables and dimension. The Likert scale used in the questionnaire are $1=$ Strongly Disagree, 2 = Disagree, 3 = Agree, $4=$ Strongly Agree. Respondents filled out the statements in this survey after they were given a treatment in a form of detail explanation and shown a mockup design of the PR Bot. 
Table 7. Technology Acceptance Model Frequencies

\begin{tabular}{|c|c|c|c|}
\hline \multicolumn{2}{|c|}{ Perceived Ease of Use } & \multicolumn{2}{|l|}{ Perceived Usefulness } \\
\hline Statements & Mean & Statements & Mean \\
\hline $\begin{array}{l}\text { PR Bot will be easy to } \\
\text { download }\end{array}$ & 3,27 & $\begin{array}{l}\text { PR Bot will make it easier for me to make a } \\
\text { Press Release }\end{array}$ & 3,10 \\
\hline $\begin{array}{l}\text { PR Bot will be easy to } \\
\text { access }\end{array}$ & 3,23 & $\begin{array}{l}\text { PR Bot will make it easier for me to } \\
\text { distribute the Press Release }\end{array}$ & 3,23 \\
\hline PR Bot will be easy to use & 3,03 & $\begin{array}{l}\text { PR Bot will speed up my completion of the } \\
\text { Press Release }\end{array}$ & 3,10 \\
\hline & & $\begin{array}{l}\text { PR Bot will reduce my fatigue in working on } \\
\text { Press Release }\end{array}$ & 3,13 \\
\hline & & $\begin{array}{l}\text { PR Bot will increase my productivity in } \\
\text { making Press Release }\end{array}$ & 3,13 \\
\hline & & $\begin{array}{l}\text { PR Bot will make my Press Release even } \\
\text { better }\end{array}$ & 2,97 \\
\hline & & $\begin{array}{l}\text { PR Bot will make it easier for the media to } \\
\text { get the Press Release from me }\end{array}$ & 3,17 \\
\hline
\end{tabular}

In the table above, it can be seen that all indicators in the Perceived Ease of Use variable have mean value above 3 . The respondent's answer to the statement submitted about the use of PR Bot is agree. Likewise in the Perceived Usefulness variable, almost all indicators have values above 3, it indicates approval of the benefits of PR Bot. There is only one indicator that has a value below 3, namely the statement "PR Bot will make my Press Release better", has a mean value of 2.97. This shows, there are some respondents who disagree that PR Bot can make better press releases than the ones traditionally made by humans.

Table 8. Attitude and Intention to Use Frequencies

\begin{tabular}{|c|c|c|c|c|c|c|c|c|c|c|c|}
\hline \multicolumn{10}{|c|}{ Attitude } & \multirow{2}{*}{\multicolumn{2}{|c|}{$\begin{array}{c}\text { Intention to } \\
\text { Use }\end{array}$}} \\
\hline \multicolumn{2}{|c|}{ Personal Advice } & \multicolumn{2}{|c|}{$\begin{array}{c}\text { Independent } \\
\text { Decision Making }\end{array}$} & \multicolumn{2}{|c|}{ Existing Product } & \multicolumn{2}{|c|}{ Savings } & \multicolumn{2}{|c|}{$\begin{array}{l}\text { High Tech } \\
\text { Product }\end{array}$} & & \\
\hline Statements & Mean & Statements & Mean & Statements & Mean & Statements & Mean & Statements & Mean & $\begin{array}{c}\text { Statement } \\
s\end{array}$ & Mean \\
\hline $\begin{array}{l}\text { I will } \\
\text { consider } \\
\text { the } \\
\text { opinions } \\
\text { of } \\
\text { relatives / } \\
\text { friends / } \\
\text { colleagues } \\
\text { before } \\
\text { using it }\end{array}$ & 2,90 & $\begin{array}{l}\text { I will } \\
\text { judge for } \\
\text { myself } \\
\text { whether } \\
\text { the PR Bot } \\
\text { is worthy } \\
\text { of my use } \\
\text { or not }\end{array}$ & 3,20 & $\begin{array}{l}\text { I accept } \\
\text { the } \\
\text { presence } \\
\text { of PR Bot } \\
\text { as a tool } \\
\text { for } \\
\text { making } \\
\text { Press } \\
\text { Release }\end{array}$ & 3,13 & $\begin{array}{l}\text { I am } \\
\text { willing to } \\
\text { spend } \\
\text { more } \\
\text { money to } \\
\text { get the } \\
\text { convenien } \\
\text { ce } \\
\text { provided } \\
\text { by PR Bot }\end{array}$ & 2,63 & $\begin{array}{l}\text { PR Bot } \\
\text { will } \\
\text { provide } \\
\text { assistance } \\
\text { to Public } \\
\text { Relations } \\
\text { in } \\
\text { preparing } \\
\text { press } \\
\text { releases }\end{array}$ & 3,13 & $\begin{array}{l}\text { I am } \\
\text { interest } \\
\text { ed in } \\
\text { trying } \\
\text { to use it }\end{array}$ & 3,17 \\
\hline
\end{tabular}




\begin{tabular}{|c|c|c|c|c|c|c|c|c|c|c|c|}
\hline $\begin{array}{l}\text { I will only } \\
\text { use it if } \\
\text { my } \\
\text { relatives / } \\
\text { friends / } \\
\text { colleagues } \\
\text { recomme } \\
\text { nd using it }\end{array}$ & 2,67 & $\begin{array}{l}\text { I will } \\
\text { switch } \\
\text { from } \\
\text { traditional } \\
\text { Press } \\
\text { Release } \\
\text { writing if I } \\
\text { rated PR } \\
\text { Bot to } \\
\text { meet my } \\
\text { needs }\end{array}$ & 3,13 & $\begin{array}{l}\text { will } \\
\text { consider } \\
\text { the } \\
\text { advantage } \\
\mathrm{s} \text { and } \\
\text { disadvant } \\
\text { ages of } \\
\text { using PR } \\
\text { Bot when } \\
\text { compared } \\
\text { to } \\
\text { traditional } \\
\text { Press } \\
\text { Release } \\
\text { builds }\end{array}$ & 3,23 & $\begin{array}{l}\text { Overall, I } \\
\text { believe } \\
\text { that the } \\
\text { presence } \\
\text { of PR Bot } \\
\text { will save } \\
\text { costs in } \\
\text { working } \\
\text { on Press } \\
\text { Release }\end{array}$ & 2,80 & $\begin{array}{l}\text { PR Bot } \\
\text { will } \\
\text { provide } \\
\text { assistance } \\
\text { to Public } \\
\text { Relations } \\
\text { in } \\
\text { managing } \\
\text { press } \\
\text { releases }\end{array}$ & 3,17 & $\begin{array}{l}\text { I intend } \\
\text { to use it }\end{array}$ & 3,10 \\
\hline \multirow[t]{3}{*}{$\begin{array}{l}\text { I will } \\
\text { invite } \\
\text { relatives / } \\
\text { friends / } \\
\text { colleagues } \\
\text { to use it }\end{array}$} & 2,93 & $\begin{array}{l}\text { will still } \\
\text { feel } \\
\text { comfortab } \\
\text { le using } \\
\text { PR Bot } \\
\text { even } \\
\text { though my } \\
\text { relatives / } \\
\text { friends / } \\
\text { colleagues } \\
\text { still } \\
\text { writing } \\
\text { Press } \\
\text { releases } \\
\text { traditional } \\
\text { ly }\end{array}$ & 2,83 & $\begin{array}{l}\text { I'm sure } \\
\text { PR Bot } \\
\text { can } \\
\text { provide } \\
\text { the same } \\
\text { comfort as } \\
\text { the } \\
\text { traditional } \\
\text { Press } \\
\text { Release } \\
\text { creation } \\
\text { that I'm } \\
\text { doing } \\
\text { today }\end{array}$ & 2,87 & $\begin{array}{l}\text { I believe } \\
\text { using PR } \\
\text { Bot will } \\
\text { save time } \\
\text { in Press } \\
\text { Release } \\
\text { processin } \\
\text { g }\end{array}$ & 3,17 & $\begin{array}{l}\text { PR Bot } \\
\text { will } \\
\text { provide } \\
\text { convenien } \\
\text { ce for } \\
\text { Public } \\
\text { Relations }\end{array}$ & 3,17 & $\begin{array}{l}\text { I will } \\
\text { definitel } \\
\text { y use it }\end{array}$ & 2,90 \\
\hline & & & & & & & & $\begin{array}{l}\text { PR Bot } \\
\text { will make } \\
\text { it easy for } \\
\text { the press } \\
\text { / media to } \\
\text { obtain a } \\
\text { Press } \\
\text { Release }\end{array}$ & 3,17 & & \\
\hline & & & & & & & & $\begin{array}{l}\text { PR Bot } \\
\text { will have } \\
\text { a positive } \\
\text { impact on } \\
\text { Public } \\
\text { Relations } \\
\text { work }\end{array}$ & 3,23 & & \\
\hline
\end{tabular}




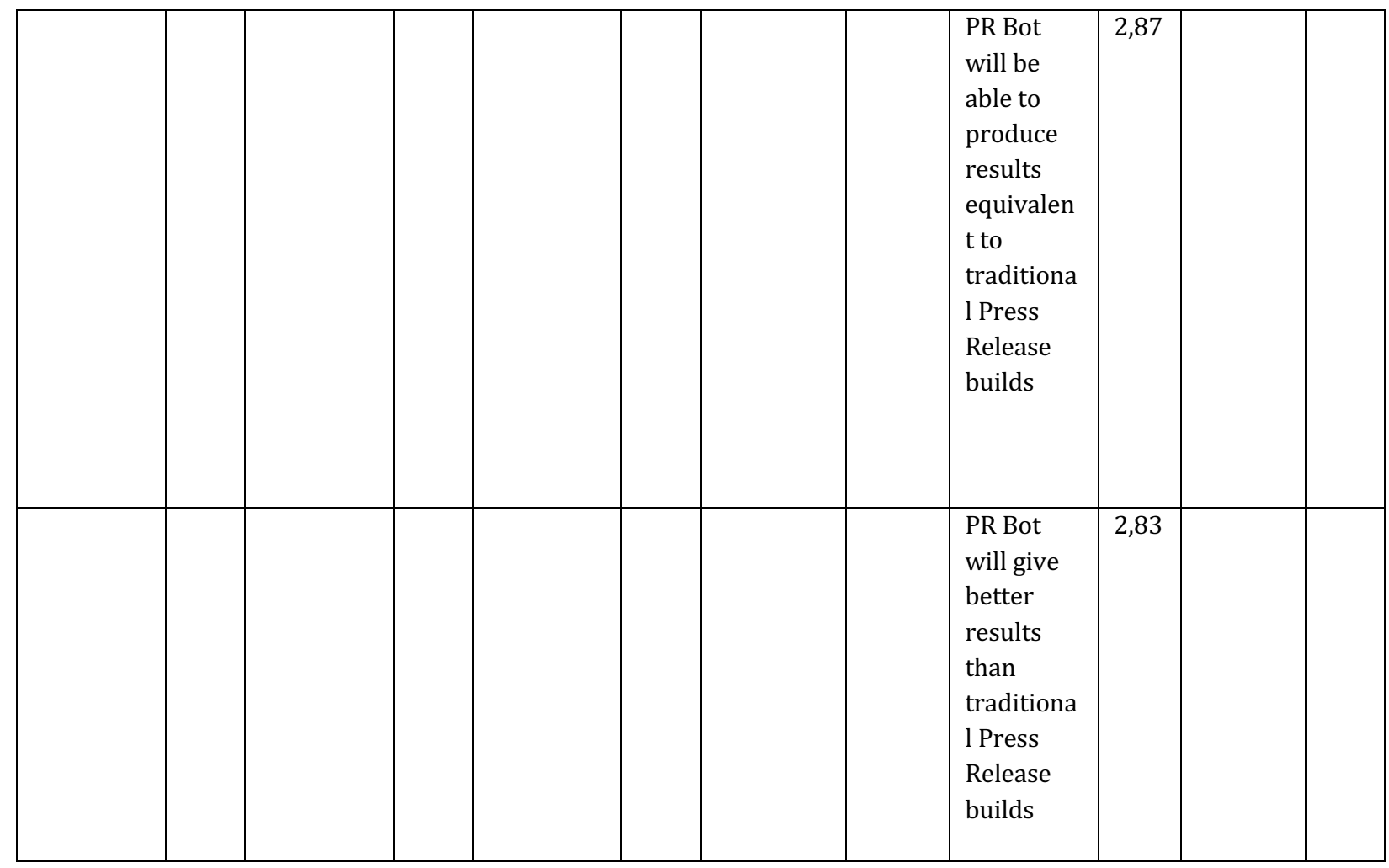

Almost all indicators of the 5 dimensions of Attitude and Intention of Use have a mean value above 3 , it means that the respondent's answer is agree. In the table above, the lowest mean value is found on the indicator "I am willing to spend more money to get the convenience provided by PR Bot". From these figures it can be concluded that there are some respondents who are still doubtful or do not agree to spend more money on using PR Bot, even though they are willing to use it. This is a good input for PR Bot development if it is going to enter the business area.

\section{CONCLUSION}

The conclusion of this research is the foundation for the development of the PR Bot application to be better. The results of the interview show that potential PR Bot users have a fairly broad insight into the development of the Industrial Revolution 4.0, especially regarding Artificial Intelligence and Machine Learning. Mastery of software that supports the use of PR Bot is also very good, they are used to using applications based on the latest technology. Another interesting point that emerged during the interviews was that they described some of the difficulties that arise when producing press releases in the traditional way. We have formulated 10 points which will be guiding us to the develop the PR Bot features.

Polls also provide meaningful input for the development of PR Bot. The use of the gadgets and internet consumption makes us confident to continue to develop PR Bot in website versions and mobile applications that can be accessed from smartphones. The PRs will 
have no trouble connecting to the internet, because the majority of them work using the internet for more than 8 hours. Another useful input is that some of our PR respondents have a habit of using a special template to make a press release. This justifies the creation of the PR Bot, that the Press Release is something that is iterative and structured so that its production can be assisted with AI-based applications.

From testing the acceptance of respondents by using TAM, the researcher got two benefits. The first benefit, after testing the validity and reliability, a valid and reliable survey instrument is formed to be used in further research with a larger sample size. The second benefit, the results of the descriptive analysis show that the target market of PR Bot is still in doubt whether PR Bot can give better results than traditional ones. In addition, they also doubt whether to spend more money on using PR Bot in the future. However, overall respondents' acceptance of PR Bot as a new technology is good. Based on the results of this results, we will continue to develop PR Bot to be more perfect and finally ready for use by PRs.

PR Bot was created not to eliminate PR. PR Bot is made to help with daily basis tasks. With routine and structured tasks that are completed more quickly, they can develop themselves, do something more strategic, and have more time to focus on other things. The use of PR Bot cannot be separated from the work and creativity of the account owner. The result of the press release is highly dependent on the Public Relations skills behind it. PR Bot will increase the effectiveness and efficiency of the production flow of a press release without threatening the profession of PR. As shown on the PR Bot logo, the letter "P" is depicted as higher than the letter "R", this implies that "People" control the "Robot", humans will always remain the main element in the Public Relations profession.

\section{REFERENCES}

Afzal, S. K. (2018, September 25). How PR is Intersecting with AI. Entrepreneur. https://www.entrepreneur.com/article/320645.

Ansari, F., Erol, S., \& Sihn, W. (2018). Rethinking Human-Machine Learning in Industry 4.0: How Does the Paradigm Shift Treat the Role of Human Learning? Procedia Manufacturing, 23, 117-122. https://doi.org/10.1016/j.promfg.2018.04.003

Arief, N. N. \& Saputra, M. A. A. (2019). Kompetensi Baru Public Relations (PR) Pada Era Artificial Intelligence. Jurnal Sistem Cerdas, 2(1), 1-12. https://doi.org/10.37396/jsc.v2i1.19

Aufa, B. A., Renindra, I. S., Putri, J. S., \& Nurmansyah, M. I. (2020). An application of the Unified Theory of Acceptance and Use of Technology (UTAUT) model for 
understanding patient perceptions on using hospital mobile application. Enfermeria Clinica, 30(6), 110-113. https://doi.org/10.1016/j.enfcli.2020.06.025

Bertrand, M. \& Bouchard, S. (2008). Applying the Technology Acceptance Model to VR with people who are favorable to its use. Journal of Cybertherapy and Rehabilitation, 1(2), 200-207.

Dunan, A. \& Mudjiyanto, B. (2020). The Republic of Indonesia Government Public Relations Communication Strategy in The Era of The Industrial Revolution 4.0. JATI-Journal of Southeast Asian Studies, 25(1), 58-78. https://doi.org/10.22452/jati.vol25no1.4

Fuchs, C. (2018). Industry 4.0: The Digital German Ideology. tripleC: Communication, Capitalism \& Critique. Open Access Journal for a Global Sustainable Information Society, 16(1), 280-289. https://doi.org/10.31269/vol16iss1pp280-289

Galloway, C. \& Swiatek, L. (2018). Public relations and artificial intelligence: It's not (just) about robots. Public Relations Review, 44(5), 734-740. https://doi.org/10.1016/j.pubrev.2018.10.008

Gershgorn, D. (2017, September 10). The Quartz guide to artificial intelligence: What is it, why is it important, and should we be afraid? QUARTZ. https://qz.com/1046350/the-quartz-guide-to-artificial-intelligence-what-is-itwhy-is-it-important-and-should-we-be-afraid/

Hair, J. F., William C., B., Barry, J. B., \& Rolph, E. A. (2014). Multivariate Data Analysis (7th Ed.). Pearson Education Limited.

Hariwijaya, M. \& Budi, T. P. (2008). Pedoman Penulisan Ilmiah Proposal dan Skripsi. Tugu Publisher.

King, W. R. \& He, J. (2006). A meta-analysis of the technology acceptance model. Information \& Management, 43(6), $\quad$ 740-755. https://doi.org/10.1016/j.im.2006.05.003

Lederer, A. L., Maupin, D. J., Sena, M. P., \& Zhuang, Y. (2000). The technology acceptance model and the World Wide Web. Decision Support Systems, 29(3), 269-282. https://doi.org/10.1016/s0167-9236(00)00076-2

Lynch, C. (2018, June 6). How PR pros should prepare for artificial intelligence. Ragan's PR daily. https://www.prdaily.com/how-pr-pros-should-prepare-for-artificialintelligence/ 
Malhotra, N. K., Nunan, D., \& Birks, D. F. (2017). Marketing Research: An Applied Approach (5th ed.). Pearson Education Limited

Mizanie, D. \& Irwansyah, I. (2019). PEMANFAATAN MEDIA SOSIAL SEBAGAI STRATEGI KEHUMASAN DIGITAL DI ERA REVOLUSI INDUSTRI 4.0. Jurnal Komunikasi, 13(2), 149-164. https://doi.org/10.21107/komunikasi.v13i2.5099

Neuman, W. (2014). Social Research Methods: Qualitative and Quantitative Approaches (7th ed.). Pearson Education Limited.

Pambudi, S. T., Utami, Y. S., \& Wiendijarti, I. (2019). Curriculum Development of Public Relations Study Programs in Era 4.0. Proceedings: International Conference on Technology, Education and Sciences, 1(1), 207-216.

Pavlik, K. V. (2007). Mapping The Consequences of Technology on Public Relations. Institute for Public Relations http://citeseerx.ist.psu.edu/viewdoc/download?doi=10.1.1.129.6285\&rep=rep1 \&type $=$ pdf.

Rouhiainen, L. (2020). Artificial intelligence: 101 things you must know today about our future. Lasse Rouhiainen.

Schwab, K. (2016). The Fourth Industrial Revolution. World Economic Forum.

Tilson, D. J. (2016). From the Natural World to Artificial Intelligence. In B.R. Brunner (Ed.), The Moral Compass of Public Relations (pp. 206-222). https://doi.org/10.4324/9781315646503-15

Frey, C. B. \& Osborne, M. A. (2013). The Future of Jobs. University of Oxford. https://www.oxfordmartin.ox.ac.uk/downloads/academic/future-ofemployment.pdf

Ustundag, A. \& Cevikcan, E. (2018). Industry 4.0: Managing The Digital Transformation. Springer International Publishing.

Valin, J. (2018). Discussion paper, Humans Still Needed: An Analysis of Skills and Tools in Public Relations. Chartered Institute of Public Relations. https://www.cipr.co.uk/sites/default/files/11497_CIPR_AlinPR_A4_vy.pdf

Venkatesh, V., Morris, M., Davis, G., \& Davis, F. (2003). User Acceptance of Information Technology: Toward a Unified View. MIS Quarterly, 27(3), 425-478. https://doi.org/10.2307/30036540 
Williams, H. (2018, March 23). How to Write a Press Release That'll Secure you PR. Meltwater. https://www.meltwater.com/uk/blog/write-press-release-thatllsecure-pr/

Yaxley, H. (2018). Outro. In A. Theaker, \& H. Yaxley (Eds.). The Public Relations Toolkit: An Essentials Guide to Successful Public Relations Practice (pp. 147-150). Routledge. 